\title{
Hospitality ERP Education in the Age of Rapidly Evolving Information Systems
}

\author{
Uday Kumar Adusumilli ${ }^{1}$, Rajneesh Pandeya ${ }^{2}$, Arvind Sebastian ${ }^{3}$, Dr. Nanda Ashwin ${ }^{4}$ \\ ${ }^{1}$ Product Support Analyst, Associate, Infor, Bangalore, Karnataka, India \\ ${ }^{2}$ Director, Support Operations, Infor, Bangalore, Karnataka, India \\ ${ }^{3}$ Manager, Support Operations, Infor, Bangalore, Karnataka, India \\ ${ }^{4}$ Professor, Department of Information Science and Engineering, East Point College of Engineering and \\ Technology, Bangalore, Karnataka, India
}

\section{ABSTRACT}

Hospitality and tourism are rapidly growing industries and are a major source of employment globally as well as in India. Tourism and hospitality industry in India will benefit more if we encourage the creation of significant numbers of jobs both directly in the hospitality sector where tourists spend their money and in related industries. Hospitality is constantly changing and progressing, creating various job opportunities. Many of them, however, are low-skilled and poorly paid. For the studies conducted as part of this research, hotel and chain hotel data was collected from a representative sample. The constructs used were limited by the metrics and instruments implemented by the company under study. Several hotel establishments were sampled for two similar studies in 2003 and 2017. An objective of the study was to determine how Enterprise Resource Planning (ERP) and e-business systems have evolved over this time period. The shortage of skilled staff can be effectively addressed by increasing the number of hotel management colleges that offer industrial training along with technology training pertaining to hospitality operations, where students can see examples of high-paying, indemand hotel careers in action and make decisions about their future careers. A skilled, motivated hotel staff will help the industry to progress. Students need to be acquainted with technology aspects, and they need to be able to utilize digital tools, systems, and technologies in order to ensure positive perceptions towards hospitality.

Keywords : Hospitality, Tourism, Hotel Chains, Enterprise Resource Planning (ERP), E-business Systems, Shortage Of Skilled Staff, Hotel Management Colleges, Industrial Training, Technology Training, Hospitality Operations.

\section{INTRODUCTION}

Throughout the country, there are several different hotel management courses. The study was specifically carried out with the final year students of hospitality management schools. The hospitality schools must provide their students with both academic and practical training in the hotel industry, as well as expose them to the technology that drives the industry. Hotel school graduates will be prepared to become industry workers with a well-defined and extensive theoretical education and extensive practical experience. The more experienced and capable students, the better their chances of success.

Copyright: (C) the author(s), publisher and licensee Technoscience Academy. This is an open-access article distributed under the terms of the Creative Commons Attribution Non-Commercial License, which permits unrestricted non-commercial use, distribution, and reproduction in any medium, provided the original work is properly cited 
Hotel industry jobs are perceived differently by trainees after their industrial training program. Hotel jobs are influenced by both job and personal matters. Although the impact of negative work experience during training is not clear to all hotel school graduates, the negative outlook will result in a negative job outlook. The theory and practical knowledge that hotel management graduates should have is yet to be settled between academicians and industry representatives. Though hotel recruiters value students with good academic backgrounds and during interviews do assess their knowledge, hotel recruiters also require entry-level staff to have strong practical understanding of the hotel industry: knowledge and skill developed through extensive work experience in the hospitality industry. These qualifications are often acquired during hotel industrial training programs. Despite being well documented, it is not uncommon for experience in the hospitality industry to alter students' perceptions of it, thus decreasing their chances.

Hoteliers no longer have a choice about adopting digital communication and information technologies (hereinafter, ICT) as the tourism industry is inextricably linked to information systems because tourism services are intangible, inseparable, seasonal, and international in nature. This has resulted in the sector being heavily dependent on ICT, and ICT has become one of the most important strategies for gaining competitive advantages, indeed, for survival of tourism companies (Medina and Plaza 2015). Hoteliers today realize that if you don't work in cyberspace, you won't sell (Cristiana, 2008). Hotels and destination countries need to be connected with cyberspace if they want to create a market niche. Tourism is being redesigned as a product, with both businesses and consumers actively participating in facilitating the redesign, and participation is being a critical component of the competitiveness of tourist organizations (Buhalis and Law, 2008). For Cladera and Martínez-Ros (2001), Using this technology contributes to the search for excellence in two ways: on one hand, it produces cost savings and optimises processes, which results in better management; and on the other, it makes it possible to provide the service in better conditions and include new services, which results in increased customer satisfaction.

A challenge for the hotel sector will be to consolidate its leadership as an innovator of tourism technology as well as a provider of tourist services. In a world that is more global and competitive than ever before, companies, especially accommodation companies, need some form of technological innovation to survive. Specifically, this study examines the establishment of enterprise resource planning (ERP) and e-business systems at a sample of hotels (both private and chains) from 2003 to 2007. Taking a theoretical framework as a reference point, we describe how ERP and e-business technologies have developed within the hotel industry.

The definition of ICT by Torres Rivera Romani (2011, p. 313) is any device (hardware or software) capable of editing, producing, storing, exchanging, or transmitting data among information systems.

Communication and collaboration using these applications, which incorporate computing resources, telecommunications and network media, can occur both interpersonally (from person-to-person) and in a multi-directional (from many-to-many). Knowledge exchange, dissemination, management, and access to knowledge is an integral part of their activities.

In general, all of these companies are using computers for business purposes and have access to the Internet. Their management systems and Internet presence are also among the most advanced (corporate and personal websites, portable devices, etc.). ICT adoption was the second highest in the hotel sector, after the information and communication sector and the professional, scientific and technical business sector, according to the study by Ure*a et al. (2017, p. 34). As new information, communication, and knowledge technologies emerge from the new global environment of the tourism market, and specifically the hotel industry, they represent an excellent 
opportunity for hotel entrepreneurs to develop their organizational systems, improve their competitiveness, and increase profitability.

Tourism companies are not experiencing the same technological and strategic changes at the same pace, which applies to other industries as well. The digital divide between large corporations and SMEs with respect to microenterprises is stronger than ever (Medina et al., 2015, p. 9). Considering this issue, DaemonQuest Deloitte's first Digital Maturity Index of hotel companies $(2015$, p. 5) reveals that $100 \%$ of large hotel chains have corporate PPPs and none of the small hotel groups do. Similar to this, $70 \%$ of big hotel chains are incorporating digital tools (robots) to personalize content and improve the guest experience at the time of booking. Moreover, $60 \%$ of hotels allow booking directly from Google. Figure 1 shows how information technology (ICT) and management technologies (ERP) have been applied to the business environment, along with other types not included in this study.

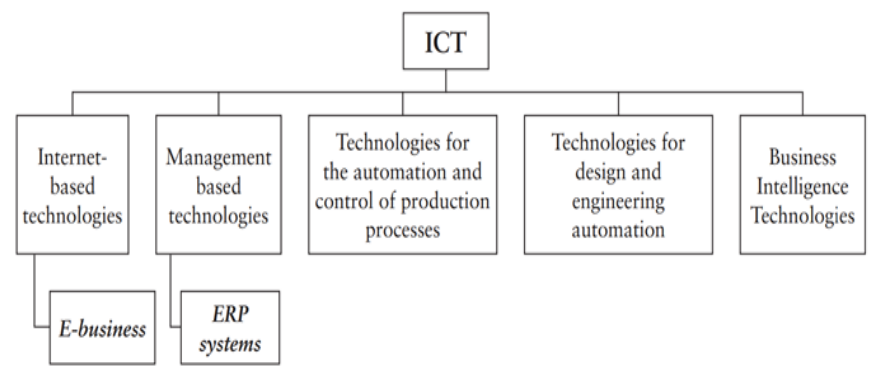

Figure 1. ICT Classification

Strategies, operational models, structured business models, and trained personnel are essential for the implementation of ICT. Because of this, in many cases, the technological strategy is inappropriately implemented, or the tools are misused, even though they are successful in generating sales. In many cases, hardware and Internet have been fully implemented, but software for management and marketing has not progressed sufficiently (Medina et al., 2015).

\section{LITERATURE REVIEW}

Only a few studies have been conducted to highlight perceptions of hotel management students regarding career opportunities in the industry despite substantial literature regarding employment in hospitality. In order to evaluate employment practices and human resource planning in the hospitality industry, more studies related to student perceptions of the industry are necessary. Hotel jobs can be perceived negatively, and a negative perception will hinder the retention of qualified, skilled workers. It is necessary for hotel management colleges to understand how hotels are perceived by college students.

Hotel school or educators can relate this to the teaching and learning process as explained by Colin Pinto (January-May 2013). In addition to receiving theoretical knowledge, students also get practical experience. Then students will have an easier time understanding what they're learning, since lecturers with actual hotel industry experience are teaching them what they have experienced in the industry. The teaching \& learning will be more effective if hotel school students are exposed to real working conditions by practically applying their knowledge.

There is a difference in expectations between a senior student who has completed an internship and a junior student who has not yet undergone industrial training, according to Data et al. (2013). A more negative outlook on the hotel industry is prevalent among these hotel school students. According to Park \& Kim (2011), students' perceptions and expectations of their future careers tend to be low after industrial training programs, suggesting a pessimistic impression of their future careers after internships. Scott Richardson explained in 2009 that students' main concerns relate to their relationships with their managers, promotion opportunities, career decisions, and the salaries and benefits offered by the hotel industry. Of the respondents with work experience in the tourism and hospitality industry, more than $50 \%$ are already pondering careers outside the industry, and more 
than $96.3 \%$ are citing the industry as the primary reason for their lack of interest after graduation.

According to a study by Van Rheede and Tromp (2009), hotel management students' expectations differed before and after enrolling. Many hospitality graduates do not enter or leave the industry without having any intention of returning. Walsh \& Taylor, 2007 Given the high turnover in the hotel industry and the difficulty of retaining well qualified staff of education, educators and industry professionals must make a concerted effort to reduce the gap between job demands and work experiences of hospitality graduates. In his study, Wenhwa Ko, 2008 emphasized how industrial training sessions brought about an improvement in supervisor satisfaction as well as education.

Regression analysis results indicate that employees who were satisfied with their training were more likely to be satisfied with their jobs and to have more confidence in their future careers. In terms of employee satisfaction during training, the administration and teaching and learning factors were found to be specifically correlated with confidence about hotel careers, while supervision by hotel employees, hotel environment, and interpersonal relationships did not. Yafang and Gong Young (2008) pointed out the negative perception hotel students have towards the industry due to lack of coordination between schools and employers, the opportunity to develop one's self, pay and welfare, work pressure, rotation of work, challenging and interesting work, and the autonomy of their job.

Over 650 hotel management students from a variety of schools evaluated a predetermined list of 20 factors that may affect students' impression of potential employers, and the factors that involve personal interaction received the highest ratings.

The most influential factors were:

(1) Consumer experience with the company;

(2) Faculty members' word of mouth.

(3) Alumni word of mouth.

(4) Personality of the hotel company representative.
(5) Feedback from other students.

(6) Guest lecturers from the industry in class.

(7) Appearances by hotel representatives.

(8) Hotel companies participating in job fairs.

(9) Three months of industrial work experience.

(10) Hotel companies sponsor tours.

\section{APPLICATION OF ERP TECHNOLOGY WITHIN THE HOTEL INDUSTRY}

Efficiencies in fundamental areas of the hotel business (such as reservations, receptions, room checks, lounges, restaurants, and relationships with vendors) have justified the development of specialized programs, for which some computer companies have emerged since the mid-Eighties. Vertical solutions, created specifically for a specific industry, have appeared on the market, as well as customized ERPs built on generic standard solutions. According to Negre Buades (2017), a hotel enterprise resource planning program offers the following advantages:

1. Integration of operating systems.

2. The performance of the organization is maximized.

3. As a result, the need for personnel in back offices is reduced.

4. The front-office staffing requirement is reduced.

5. It allows the hotel to monitor all areas of the building.

6. With dynamic reports, you can make better decisions.

\section{THE APPLICATION OF E-BUSINESS TO THE HOTEL SECTOR}

New tourism intermediaries have emerged as a result of e-business. Rodrguez-Zulaica, Pastor and Ara (2017) define tourism intermediaries as those who connect the main tourist agents with the consumers. They transfer the right of usage from one to another in exchange for economic profit and assume the risks related to the sales transaction. Business-to-business 
(B2B) is a minority model used by wholesale travel agencies, while B2C (business-to-consumer) has historically been the principal model used by tourism intermediaries.

As e-business and the internet have penetrated into homes across the globe, new types of travel distribution companies have emerged: OTAs (online or virtual travel agencies), online auctions, GDSs, CRSs or infomediaries. Another development was the rise of online brokers. OTAs and other intermediaries are increasingly integrated into hotel companies' ERP systems, and hotels are investing in technology to improve their websites and reduce their dependence on them. They buy their trips by improvising and adopting the budget and offers they find on the internet.

As the hotel market is highly competitive, the homepage of a website must have a high degree of perceived visual appeal (López \& Garc*a, 2018). By analyzing and filtering the data that users provide, online intermediaries can provide customers with information in a personalised format. Due to the volume of information on the web, middlemen who can manage it best will offer their customers the highest added value (Rodr*guez-Zulaica et al., 2017). Having alliances with each other in the value chain is another key aspect of e-business, as this allows customers to contract the hosting service and other related services while on site.

\section{METHODOLOGY OF THE STUDY}

Specifically, the study will examine the degree to which hotel establishments implemented and used ebusiness systems and ERP software during two separate time periods. Two major surveys have been conducted in recent years: the first is from 2003 (Partearroyo 2007); the second is the subject of this study. It has been possible to develop ERP/e-business scenarios for the companies based on the research and to observe how they have evolved since 2003.
An analysis of 16 hotel chains and 23 hotels in the Community of Madrid between 2003 and 2017 was carried out on a sample of hotels up to five stars rated in both years. Although, at first glance, this sample may seem small, the fact is that the hotel chain data can be extrapolated to all the hotels in the chain, since the questions have always been about the management of the remaining hotels. Because of the large market share of hotel chains in Spain, a small sample can be highly representative of all hotels in the country, thanks to the $39 \%$ share of establishments and the $63 \%$ share of rooms for hotels in the country.

Table 3. Migration towards new ERP/e-business scenarios

\begin{tabular}{l|llll}
\hline & $\begin{array}{c}\text { No e-business } \\
\text { capabilities }\end{array}$ & $\begin{array}{c}\text { Channel } \\
\text { improvement }\end{array}$ & $\begin{array}{c}\text { Value chain } \\
\text { integration }\end{array}$ & $\begin{array}{c}\text { Industry } \\
\text { Transformation }\end{array}$ \\
\hline From scratch & & & & \\
\hline $\begin{array}{l}\text { Non-integrated } \\
\text { systems }\end{array}$ & & & & \\
\hline $\begin{array}{l}\text { Limited or sole } \\
\text { purpose ERP }\end{array}$ & & & & \\
\hline Business Unit ERP & & & & \\
\hline $\begin{array}{l}\text { ERP in an } \\
\text { integrated } \\
\text { company }\end{array}$ & & & & \\
\hline
\end{tabular}

Table 1. Ideal Migration Scenario towards ERP Solutions

Data were obtained through personal interviews with hotel managers, for which no standardised questionnaire was used. As a result, a dialogue was held with the manager interviewed, following a script that included the following points:

- A description of the business management information system and its computerized functions.

- Degree of satisfaction with the current system (the advantages and disadvantages of it and whether they think it enabled them to make a profit

- They should also consider their future prospects (if they plan to implement ERP systems)

- Adding more modules or changing the system, if they don't have one already.

- The hotel's e-business operations and their current state 
- Their current state of development.

- Future e-business prospects (what new e-business technology tools the hotel or chain plans to add).

In addition to gathering information, the open interviews had another objective and that was to Identify how the hotels' information systems would function in each scenario and to position the hotels accordingly. The findings of this study have developed over the last decade. Thus, we have asked them to explain how they have evolved in their ERP and E-business systems to get to this point. Setting the scene is shown in Table 4.

\begin{tabular}{|c|c|}
\hline ERP phase & ERP phase indicators \\
\hline From scratch & They do not use business management programmes. \\
\hline Non-integrated systems & They use non-integrated management programmes. \\
\hline Sole purpose ERP & They use some module of an ERP with other non-integrated systems. \\
\hline Business unit ERP & They use different ERPs for different business units. \\
\hline Integrated ERP & They use the same ERP for the whole chain. \\
\hline E-business phase & E-business phase indicators \\
\hline No capacities & They do no e-business. \\
\hline Channel improvement & $\begin{array}{l}\text { They run marketing activities, purchasing or selling services on the } \\
\text { Internct. }\end{array}$ \\
\hline Value chain integration & $\begin{array}{l}\text { Integrated electronic value chain with suppliers, intermediaries and } \\
\text { customers. }\end{array}$ \\
\hline Transformation & $\begin{array}{l}\text { Digital transformation of the value chain and the main business processes } \\
\text { (intranets connected through the Internet). }\end{array}$ \\
\hline Convergence & $\begin{array}{l}\text { Online grouping with other companies in the same sector or another } \\
\text { takeaway sector (online agencies, taxis, cleaning services, other chains, } \\
\text { platforms, clusters) to provide joint goods and services. }\end{array}$ \\
\hline
\end{tabular}

Table 2. E-business/ERP indicators for hotels

The hotel samples are different as, over the years, there have been hotels that have disappeared or changed their names as well as some that did not exist in 2003. To be able to compare the current situation with the future, samples are used that demonstrate a percentage of hotels similar to those in the sample.

As a result, we will present two snapshots of history in two different time periods:

Approximately 75\% (in 2003) and 70\% (in 2017) of hotels analyzed are chains (defined as having more than two establishments), while the rest were Owned privately.

- $62.5 \%$ and $60 \%$ respectively of the establishments studied had more than 100 rooms.

- $50 \%$ and $56 \%$ respectively of the hotels surveyed were 4-star hotels.

- The Sol-Meliá, NH and Occidental hotel chains, and the Paradors, were all included in both samples.
VI. RESULTS

\section{A. Results obtained in 2003}

Analyzing data from the 2003 sample of hotels, table 4 displays the possible ERP/e-business scenarios.

\begin{tabular}{|c|c|c|c|c|c|}
\hline & $\begin{array}{l}\text { With no } \\
\text { e-business } \\
\text { capability }\end{array}$ & $\begin{array}{l}\text { Improvement } \\
\text { in channel }\end{array}$ & $\begin{array}{l}\text { Value chain } \\
\text { integration }\end{array}$ & $\begin{array}{c}\text { Industry } \\
\text { transformation }\end{array}$ & Convergence \\
\hline \multicolumn{6}{|l|}{ From scratch } \\
\hline $\begin{array}{l}\text { Non-integrated } \\
\text { systems }\end{array}$ & & 000 & & & \\
\hline $\begin{array}{l}\text { Limited or sole } \\
\text { purpose ERP }\end{array}$ & $\begin{array}{l}\text { III. Limited } \\
\text { Reduced e- } \\
\bigcirc\end{array}$ & $\begin{array}{l}\text { stomer benefits. } \\
\text { iness option }\end{array}$ & & & \\
\hline $\begin{array}{l}\text { ERP in } \\
\text { business unit }\end{array}$ & & 000 & V. Optimisat & $\mathrm{n}$ at the business $\mathrm{u}$ & it level \\
\hline $\begin{array}{l}\text { ERP in an } \\
\text { integrated } \\
\text { company }\end{array}$ & & 000 & $\begin{array}{l}\text { VI. Optimisa } \\
\bigcirc \bigcirc \bigcirc\end{array}$ & ion of the company & \\
\hline
\end{tabular}

Table 5. Hotel ERP/eBusiness scenarios in 2003

A primary conclusion of the 2003 study was that most hotels were at the e-business stage of improving their channel as they used their own web pages for marketing and for making reservations, but few provided electronic payment, although they gave the user the option of providing a credit card number to guarantee the reservation. Participants who found themselves in this scenario justified their position by arguing that online payments create a sense of insecurity for customers. As a result, the position (limited customer benefits, reduced e-business options) offers hardly any advantage. Customers are limited by the benefits available to them and the environment is only flexible to a certain extent.

\section{B. Results obtained in 2017}

As of 14 years ago, when Partearroyo (2007) published his study, the hotel industry has undergone fundamental changes and advances. There has been a significant increase in the e-business interactions of hotel establishments over the past few years, primarily due to the proliferation of different electronic distribution channels (Rodrguez-Zulaica, Pastor and Ara, 2017). The 2007 study, similar to that of 2003, included the ERP/e-business matrix along with an alternative snapshot, as shown in Table 7. 


\begin{tabular}{|c|c|c|c|c|c|}
\hline & $\begin{array}{l}\text { With no } \\
\text { e-business } \\
\text { capability }\end{array}$ & $\begin{array}{l}\text { Improvement } \\
\text { in channel }\end{array}$ & $\begin{array}{l}\text { Value chain } \\
\text { integration }\end{array}$ & $\begin{array}{l}\text { Industry } \\
\text { transformation }\end{array}$ & Convergence \\
\hline \multicolumn{6}{|l|}{ From scratch } \\
\hline $\begin{array}{l}\text { Non-integrated } \\
\text { systems }\end{array}$ & & & \multicolumn{3}{|c|}{ IV. I Iigh costs in relation to profit } \\
\hline $\begin{array}{l}\text { Limited or sole } \\
\text { purpose ERP }\end{array}$ & \multicolumn{2}{|c|}{$\begin{array}{l}\text { III. Limited customer benefits. } \\
\text { Reduced e-business option } \\
\end{array}$} & 0 & \multicolumn{2}{|l|}{$0 \circ 0$} \\
\hline $\begin{array}{l}\text { ERP in } \\
\text { business unit }\end{array}$ & & & \multicolumn{3}{|c|}{\begin{tabular}{|l|} 
V. Optimisation at the business unit level \\
000
\end{tabular}} \\
\hline $\begin{array}{l}\text { ERP in an } \\
\text { integrated } \\
\text { company }\end{array}$ & & & \multicolumn{2}{|c|}{ VI. Optimisation of the company } & 00000 \\
\hline
\end{tabular}

Table 7. The ERP/E-business scenarios used in the hotel industry in 2017

One hundred percent of the sample in 2017 used an ERP. Upon analysis of the responses, it was determined that hotel chains tended to use ERP systems already developed on the market for this industry, and improved them accordingly to fit the hotel's needs. It was not the case in small establishments, which used a variety of more affordable and diverse ERP systems.

\section{OBSERVATIONS}

In the hotel management program, students learn professionalism in hotels as part of their industrial training. This professionalism is further developed after the program. As a result, students gain confidence, a positive attitude, and a respectable approach to the hotel industry. The practical experience students receive is important in determining whether they want to pursue a career in the industry after their training. There are various departments within hotels in which the students work, and they are generally satisfied with their working environment. While they master the basics of their job in school, they get the opportunity to apply their theoretical knowledge in the hotel by dealing directly with hotel guests and by interacting with various situations and situations that arise. Students are exposed to real-life hotel industry work through their industrial training programs. Interest in Working in the Hotel Industry: Because many students do differ in their previous decisions about their career in the hotel industry after experiencing real work scenarios of hotels, some may end up favouring working in hotels, while others may not. Following industrial training, students usually choose their department of choice where they would like to pursue a career.

\section{DISCUSSION}

Based on the results, it can be concluded that hotels and hotel chains have evolved in both directions, focusing on e-business scenarios rather than ERP scenarios. The hotel establishments interviewed all have their own websites where online reservations can be made and are also present on online intermediaries (such as expedia.com, booking.com, , oyo.com, etc) and in global distribution systems, thereby expanding their global reach. A noteworthy development is the disappearance of distrust associated with using the Internet for financial transactions. The majority of hotels interviewed have arranged electronic procurement directly through their own vertical supplier portals or through eprocurement service providers. Despite having changed their ERPs relatively recently, many hotels reported that they were satisfied with their respective ERPs in 2017.

\section{RECOMMENDATIONS}

The following recommendations are useful for hotel industry students, particularly those in the final year of their hotel management programs:

There needs to be good coordination between hotel recruiters, hotel management schools, and technology training institutes. A qualified workforce for hotel jobs will be available as a result of this. Recruiters will also have more information about certain hotel jobs and be able to coordinate with tech training institutes so the necessary training can be provided to students. 
- Industrial trainees should have enough opportunities to learn both the hotel management and the hotel's digital operations, which will encourage them to enter the hotel industry after they graduate.

- The students should get experience working in each department of the hotel (including the technical departments) and also should get responsibilities that will help boost their confidence about a hotel industry job and also help increase the respect towards a hotel industry job.

- For students to gain a solid understanding of the hotel work culture, they should receive good training. The role also involves collaborating and coordinating with Hotel Chains' divisions of EPV suppliers and other technology partners.

- There are several points the hospitality industry needs to keep in mind when interacting with students who have just graduated. Training programs should be structured so that students enjoy sessions, and not find the training stressful.

\section{CONCLUSION}

Two similar studies on the evolution of ICT in our study were conducted within two years, 2003 and 2017, focusing on three aspects: The hotel industry, and especially the large hotel chains, have been the most proactive in using ICT. Despite the peculiarities of the hotel sector, it is mostly managed by enterprise resource planning (ERP) software that is specifically designed for hotel management, though hotel owners modify the software to suit their needs.

A very small amount of e-business was conducted by hotels in 2003. The potential of websites was not exploited, as they were used primarily for advertising and sometimes for making reservations. Investing in ERP software seemed to be the industry's priority, which left e-commerce to one side. As of recent years, the hotel sector has also recognized the benefit of participating in social networking sites to make itself known, promote its products, and meet customers more directly. (Rivero and Rangel, 2016).

Research on the perception of hotel industry work among hotel management college final year students was conducted. Students who have experienced industrial training in a hotel for their final year of hotel management are interviewed for this study. This research project examined how hotel job culture impacts hotel management students. Students' responses indicate that most change their attitudes once they become employed in the hotel industry during their industrial training. Hotel students are generally satisfied with their training, but many are still uncertain about working in the hotel industry after graduating. Furthermore, students decide where they plan to work after graduation based on the department of their choice.

Hotel jobs are regarded as having average promotion opportunities, according to students' observations, and the vast majority of final year students are not particularly attracted to careers in the hotel industry. With technology enabling roles and positions, however, this isn't the case. Investing in hotel management school, should the right opportunities and the right salary opportunities be offered, is generally the right decision for hotel management students.

\section{REFERENCES}

[1]. Anoop Patiar, E. M. (2016). Hospitality Management Students' Expectation and Perception of a Virtual Field Trip Website: An Australian Case Study Using ImportancePerformance Analysis. Griffith Business School.

[2]. Brown, E. A. (2011). Hospitality management graduates' perceptions of career factor importance and career factor experience and the relation with turnover intentions. Graduate Theses and Dissertations.

[3]. El-Houshy, S. S. (2014). towards Working in Hotels: a case study of the faculty of tourism and 
hotels in Alexandria University Hospitality Students' Perceptions. Tourism In A Changing World: Opportunities \& Challenges, (pp. 800819). Egypt.

[4]. Eric A. Browna*, S. W. (2014). Hospitality management graduates' perceptions of career factor importance and career factor experience. International Journal of Hospitality Management.

[5]. Lashley, C. (2013). Student employment in hospitality and tourism: insights from a recent study. Research in Hospitality Management , 1-8.

[6]. Lusby, C. (2017). American and Macau student perceptions towards working in the tourism and hospitality industry. International Interdisciplinary Business -Economics Advancement Journal,vol-2 , 54-64.

[7]. Nicolae Lupu, M. O.-M. (2014). Perception About Business Education In The Tourism Domain And The Hospitality Industry. Business Education in the Tourism Domain and the Hospitality Industry , 800-810.

[8]. Jarvenpaa, S. L. and B. Ives. 1991. Executive involvement and participation in the management of information technology. MIS Quarterly, 15:2, 205-227.

[9]. Krumbholz, M., Galliers, J., Coulianos, N. and N. A. M. Maiden. 2000. Implementing enterprise resource planning packages in different corporate and national cultures. Journal of Information Technology, 15:4, 267-279.

[10]. Kumar, V., Maheshwari, B. and U. Kumar. 2002. Enterprise resource planning systems adoption process: A survey of Canadian organizations. International Journal of Production Research, 40:3, 509-523.

[11]. Lee, Z. and J. Lee. 2000. An ERP implementation case study from a knowledge transfer perspective. Journal of Information Technology, 15:2, 281-288.

[12]. Mabert, V. A., Soni, A., and M. A. Venkataramanan. 2003. Enterprise resource planning: Managing the implementation process. European Journal of Operational Research, 146:2, 302-314.

[13]. Mabert, V. A., Soni, A., M. A. Venkataramanan. 2003. The impact of organization size on enterprise resource planning (ERP) implementations in the US manufacturing sector. Omega, 31:3, 235-246.

[14]. Obrien, P. W. (2014). Climbing The Hospitality Career Ladder: Career Guidance Insights From Social Networking Profiles. Journal of Tourism and Hospitality Management vol-2, 1-17.

[15].Öztin, A. R. (2007). Career Perceptions of Undergraduate Tourism Students: A Case Study in Turkey. Journal of Hospitality, Leisure, Sport and Tourism Education 6(1) , 4-17.

[16]. Rajeshree S. Pol*, H. P. (2015). Perception of Final Year Hotel Management Students towards Working in the Hotel Industry. Atithya: A Journal of Hospitality , 47-53.

[17]. Ross, G. F. (1993). Tourism and Hospitality Employment and Career Perceptions Among High School Students. Visions in Leisure and Business: Vol. 12 : Iss. 1 , Article 3 , 13-33.

[18]. Seongseop (Sam) Kim a, n. (2016). Hospitality and tourism management students' study and career preferences: Comparison of three Asian regional groups. Journal of Hospitality, Leisure, Sport \& Tourism Education 19 (2016) 66-84, 6684.

[19]. Erdogan, N., \& Baris, E. (2007). Environmental protection programs and conservation practices of hotels in Ankara, Turkey. Tourism Management, 604-614.

[20]. Ministry of Tourism. (2014). Guidelines and Implementation of Green Hotel in Indonesia. Jakarta.

[21].Al., Z. M. (2016). Graduates' Perception on the Factors Affecting Commitment to Pursue Career in the Hospitality Industry. Procedia - Social and Behavioral Sciences, 416-420. 
[22]. Anastasios Zopiatis, G. K. (2006). Perceptions and attitudes towards the hospitality professions in cyprus. Tourism Today, 33-46.

[23]. Anoop Kumar, P. K. (2014). An investigation of the perception of hospitality graduates towards the industry: a gender perspective. African Journal of Hospitality, Tourism and Leisure Vol. 3 (2) . International Journal of Psychosocial Rehabilitation, Vol. 24, Issue 06, 2020 ISSN: 1475-7192 Received: 22 Sep 2019 | Revised: 13 Oct 2019 | Accepted: 15 Jan 20204971.

[24]. Brown, C. and I. Vessey. 1998. ERP implementation approaches: Toward a contingency framework. Nineteenth International Conference on Information Systems, 411-416.

[25]. Aladwani, A. M. 2002. An integrated performance model of information systems projects. Journal of Management Information Systems, 19:1, 185-210. 